\title{
Dampak Pelatihan "Count Me In" Bagi Penguatan Kerelawanan (Volunteering) dalam Civil Society Organization (CSO)
}

\author{
${ }^{1}$ Adiyati Fathu Roshonah, ${ }^{2}$ Tjahjo Suprajogo \\ ${ }^{3}$ Agus Yuniawan Isyanto, ${ }^{4}$ Diah Andika Sari ${ }^{4}$ \\ ${ }^{1,4}$ Universitas Muhammadiyah Jakarta \\ ${ }^{2}$ Institut Pemerintahan Dalam Negeri Jakarta \\ ${ }^{3}$ Universitas Galuh Ciamis \\ Email : adiyati.1809@gmail.com
}

\begin{abstract}
Public education has a strategic position in developing human resources and encouraging the improvement of the quality of education through the principle of lifelong education. Although the scope is not as intensive as formal education, its role cannot ignore in the effort to educate the nation's life. Community education involves many individuals in Civil Society Organizations (CSO). One way to increase the capacity and capability of human resources in organizations is through training activities (training). NICE Foundation Indonesia has filled out Count Me In Training for volunteers who have been contributing to community education. This study conduct to evaluate the Count Me In Training of 10 (ten) CSOs using the Kirkpatrick \& Kirkpatrick Four Level Evaluation Model. The results showed objectives Count Me In Training achieved as evidenced by an increase in knowledge and changes in the behaviour of participants, as well as an increase in individual and organizational performance in volunteerism management.
\end{abstract}

Keywords: Count Me In Training, Civil Society Organization (CSO). Evaluation Model Four Levels of Kirkpatrick \& Kirkpatrick.

\section{Pendahuluan}

Kesukarelaan (volunteerism) adalah fenomena global dan nasional yang memiliki potensi untuk membantu pemerintah dalam menyajikan program dan kebijakan publik yang lebih baik. Kesukarelaan adalah kekuatan yang powerful untuk pencapaian tujuan-tujuan pembangunan milenium (UN General Asembly dalam Rochester, et al.) ${ }^{1}$.

Eksistensi dan kiprah organisasi masyarakat sipil (civil society organization) sangat impactfull dan strategis dalam menjawab persoalan masyarakat. Kehadirannya membantu tugas pemerintah.dan meringankan tanggung jawab dalam memberikan pelayanan bagi masyarakat. Keberadaan dan peran CSO di dunia mencapai puncaknya terutama di tahun 1990-an (Armstrong, et al.) ${ }^{2}$. Dalam konteks Indonesia perkembangan CSO di era reformasi telah menandai kebangkitan demokratisasi. Hal ini merupakan suatu fenomena yang menarik berkembang di berbagai arena. Organisasi masyarakat sipil lahir dari komunitas yang berbasis pada kepedulian, kepercayaan dan kerja tim serta diikat bersama oleh sistem yang kuat dan efektif untuk komunikasi dan resolusi konflik. Sifat dasar interaktif komunitas menjembatani

1 Rochester, Angela E.Paine, Zimmeck, 2010, Volunteering and Society in the 21st Century, Palgrave MacMillan Pubsliher, USA, p.1

2 Armstrong, David, Valeria Bello, J. Gilson, D.Spini, 2011, Civil Societ and International Governance: the Role of Non-State Actors in Global and Regional Regulary Frameworks, First Published, Routledge/GARET-series, Europe, USA 
antara individu dan kolektivitas serta mempertemukannya (Denhart dan Denhart dalam Suprajogo) ${ }^{3}$.

Salah satu cara meningkatkan kapasitas dan kapabilitas sumber daya manusia dalam organisasi adalah melalui aktivitas pelatihan (training), yakni apapun prosedur yang diinisiasi oleh organisasi untuk membantu mengembangkan pembelajaran diantara anggota-anggota organisasional (Chrude dan Sherman) ${ }^{4}$. Pakar SDM mendefinisikan secara khusus terkait dengan tujuan organisasi ataupun perusahaan membekali para pekerjanya dengan suatu kompetensi tertentu (Boxall, et al. $)^{5}$.

Menurut Biech ${ }^{6}$ training is the activity conducted by adults who are learning new skills, atau kegiatan yang dilakukan oleh orang dewasa yang sedang mempelajari keterampilan baru. Substansi dasar dan inti dari pelatihan adalah proses pembelajaran. Tujuan pelatihan adalah mampu membuat pesertanya memiliki kemauan dan keinginan kuat untuk terus-menerus belajar secara berkesinambungan. Biasanya dirangkaian antara pelatihan (training) dan pengembangan (development). Biasanya pelatihan bertujuan mencapai sasaran-sasaran organisasi yang spesifik dalam jangka pendek, adapun pendidikan diarahkan menuju pengembangan individu dalam jangka panjang (Tyson, 2006) ${ }^{7}$.

Secara umum, kesepuluh CSO yang menjadi peserta Pelatihan Count Me In dalam penelitian ini tergolong sebagai CSO yang berbasis pada kesukarelaan meskipun di dalam pengelolaan organisasi dan manajemen ada personil yang bertugas full- time dan part-time.

\section{Kajian Teori}

Berdasarkan penelusuran dalam Oxford Advanced Learner's Dictionary kata voluntary diartikan sebagai acting, done or given willingly, working, done or maintaned without payment. Sedangkan orangnya menurut Edwards ${ }^{8}$ dijuluki volunteer yakni a person who offers to do something without being forced, a person who works for an organization but is not paid for what he or she does atau seseorang yang menawarkan untuk melakukan sesuatu tanpa dipaksa, seseorang yang bekerja untuk sebuah organisasi tetapi tidak dibayar untuk apa yang dia lakukan.

Adapun menurut Wilson", volunteering means any activity in which time is given freely to benefit another person, group, or organization. Peneliti lain mendefinisikan sebagai any activity which involves spending time, unpaid, doing something that aims to benefit (individuals or groups) other than or in addition

\footnotetext{
${ }^{3}$ Suprajogo, Tjahjo, 2011, Manajemen Pelayanan Publik Dalam Paradigma Baru Pemerintahan: Konsep, Desain dan Implementasi, Institut Pemerintahan Dalam Negeri, Jakarta, pp. 57-58

${ }^{4}$ Chruden, Herbert J., Sherman, Arthur W., 1984, Managing Human Rosources, Seventh Edition, SouthWest Publishing Co., Ohio, USA, p. 185

${ }^{5}$ Boxall, Peter, Purcell, John, Wright, Patrick, 2007, The Oxford Handbook of Human Resources Management, Oxford University Press Inc., USA, p. 328

${ }^{6}$ Biech, Elaine, 2017, the Art and Science of Training, the Association of Talent Development (ATD) Press, USA, p. 3

${ }^{7}$ Tyson, Shaun, 2006, Essentials of Human Resource Management, Fifth Edition, Published by Elsevier Ltd, USA, p. 214

${ }^{8}$ Edwards, Michael, 2011, The Oxford Handbook Of Civil Society, Oxford University Press, Oxford

${ }^{9}$ Wilson, John dan Mare Musick, 1997, Who Cares? Toward an Integrated Theory of Volunteer Work, American Sociological Review, Vol 62 (October)
} 
to, close relatives, or the benefit of the environment atau kegiatan apapun yang melibatkan menghabiskan waktu, tidak dibayar, melakukan sesuatu yang bertujuan untuk memberi manfaat (individu atau kelompok) selain atau sebagai tambahan, kerabat dekat, atau manfaat lingkungan. Pengertian ini tidak menghalangi para relawan memperoleh manfaat dari kerja mereka. Apakah manfaat ini termasuk berupa hadiah materi, hal ini masih terbuka untuk diperdebatkan. Beberapa sarjana memandang bahwa pekerjaan adalah benar-benar bukan volunteering (kesukarelaan) apabila mendapatkan upah (renumeration). Jadi secara sederhana, penulis mendefinisikan volunteering sebagai aktivitas yang tidak dibayar atau mendapatkan upah, yang dilakukan untuk memberikan manfaat bagi banyak orang tanpa terkecuali, apapun alasannya.

Terhitung tahun 1980-an, aktivitas kesukarelaan mencuat ke permukaan sebagai suatu gerakan di tengah-tengah masyarakat. Seiring menguatnya pengaruh dan dampak globalisasi, muncul, tumbuh dan berkembang kesukarelaan, meskipun sesungguhnya kesukarelaan sudah ada sejak manusia pertama hadir di dunia ini. Kesukarelaan dan para relawan kian marak ketika terjadi persoalan-persoalan sosial, ekonomi, pendidikan, dan sebagainya diantara masyarakat. Terutama ketika dihadapkan dengan berbagai peristiwa yang menuntut simpati, empati, kepedulian, dan bahkan kerelaan orang lain untuk membantu sesamanya. Antara lain muncul pada saat terjadi peristiwa, seperti gempa bumi, tsunami, longsor, penyakit menular, kelaparan dan sebagainya. Meskipun beraneka ragam bentuknya, namun entitas ini memiliki beberapa karakteristik umum, yakni (1) berbentuk organisasi, pribadi (partikelir) yaitu secara kelembagaan terpisah dari negara, (2) tidak bertujuan mencari keuntungan (non profit distributing), (3) menangani dan mengurusi sendiri (self-governing) dan (4) sukarela (voluntary) yang mana keanggotaannya secara legal tidak dipersyaratkan dan mereka menawarkan beberapa tingkat konstribusi sukarela baik berupa waktu maupun uang (Salamon,et.al.,1999) ${ }^{10}$. Kesukarelaan dalam konteks Indonesia dapat beragam bentuk seperti donor darah, santunan yatim, berbagi pengetahuan dan pengalaman terbaik, arisan, zakat, infaq dan sedekah, mengajar, gotong royong, saweran, penyuluhan kesehatan, bina balita, dan sebagainya.

\section{Metodologi Penelitian}

Pendekatan yang digunakan dalam penelitian ini adalah penelitian kualitatif, yakni suatu proses penelitian dan pemahaman yang berdasarkan pada metodologi yang menyelidiki suatu fenomena sosial dan masalah manusia. Pada pendekatan ini, peneliti membuat suatu gambaran kompleks, meneliti kata-kata, laporan terinci dari pandangan responden, dan melakukan studi pada situasi yang alami (Creswell, 2007) ${ }^{11}$. Bogdan dan Taylor (Moleong, 2007) ${ }^{12}$ mengemukakan bahwa metodologi kualitatif merupakan prosedur penelitian yang

\footnotetext{
10 Salamon, Lester M., Helmut K. Anheier, et.al., 1999, Global Civil Society: Dimensions of the Nonprofit Sector, The John Hopkins Center for Civil Society Studies, Baltimore, USA, pp. 3-4

${ }^{11}$ Creswell, John W., 2007, Qualitative Inquiry and Research Design: Choosing Among Five Approaches, Second Edition, Sage Publication, California, USA, p.15

12 Moleong, Lexy J., 2007, Metodologi Penelitian Kualitatif, Penerbit PT Remaja Rosdakarya. Offset, Bandung, p. 3
}

AL-MURABBI: Jurnal Studi Kependidikan dan Keislaman Vol. 7, No. 1 (2020) 
menghasilkan data deskriptif berupa kata-kata tertulis maupun lisan dari orang-orang dan perilaku yang diamati. Penelitian kualitatif dilakukan pada kondisi alamiah dan bersifat penemuan.

Penelitian kualitatif yang dipergunakan oleh peneliti adalah deskriptif-kualitatif, Penelitian deskriptif bertujuan menggambarkan secara sistematik dan akurat fakta dan karakteristik mengenai populasi atau mengenai bidang tertentu. Penelitian ini berusaha menggambarkan situasi atau kejadian. Data yang dikumpulkan semata-mata bersifat deskriptif sehingga tidak bermaksud mencari penjelasan, menguji hipotesis, membuat prediksi, maupun mempelajari implikasi. Dari sisi tujuan dan kegunaan, penelitian ini adalah penelitian evaluasi (evaluation research), yaitu untuk membandingkan suatu kejadian, kegiatan dan produk dengan standard dan program yang telah ditetapkan (Sugiyono, 2000) ${ }^{13}$.

Penelitian evaluasi adalah penilaian sistematik tentang sesuatu yang bernilai ataupun bermanfaat mengenai beberapa obyek. Evaluation is the systematic assessment of the worth or merit of some object. (Denzin and Lincoln, 1994) ${ }^{14}$. Penelitian evaluasi ini dilakukan terhadap Pelatihan Count Me In pada 10 (sepuluh) CSO yang telah dilaksanakan oleh Tim Training NICE Foundation Indonesia pada September-Oktober 2019. Penelitian ini merupakan penilaian sistematis dan obyektif tentang aktivitas dalam proses yang sedang berjalan, mengetahui, mencermati dan menganalisa bagaimana kesesuaian antara pelaksanaan dengan perencanaan yang telah ditentukan. Juga melihat sejauh mana tujuan ataupun target yang sudah ditetapkan tercapai dan keluaran serta dampak dari pelatihan yang telah dilakukan terhadap 10 (sepuluh) CSO yang telah ditentukan.

Dalam penelitian ini, model yang dipergunakan adalah mengevaluasi program pelatihan 4 (empat) level yang dikemukakan oleh Donald L. Kirkpatrick dan James D. Kirkpatrick $(2008)^{15}$. Menurut Kirkpatrick dan Kirkpatrick, terdapat beberapa faktor yang harus dipertimbangkan ketika merencanakan dan mengimplementasikan sebuah program pelatihan yang efektif yaitu: (1) Menentukan kebutuhan, (2) Menyusun sasaran-sasaran, (3) Menentukan isi subyek, (4) Menyeleksi peserta, (5) Menentukan jadwal terbaik, (6) Menyeleksi fasilitas yang layak, (7) Menyeleksi instruktur yang layak, (8) Menyeleksi dan menyiapkan bantuan audio visual, (9) Mengkoordinasikan program, (10) Mengevaluasi program. Selanjutnya, menurut Kirkpatrick dan Kirkpatrick, terdapat 4 (empat) level menunjukkan urutan cara untuk mengevaluasi program meliputi Level 1-Reaksi, Level 2-Belajar, Level 3-Perilaku, Level 4Hasil

1. Level 1-Reaksi, yakni mengukur bagaimana para peserta yang terlibat dalam pelatihan bereaksi. Biasanya pengukuran ini disebut pengukuran kepuasan peserta. Reaksi dari peserta yang selesai mengikuti pelatihan itu akan sangat menentukan berlanjut tidaknya program pelatihan tersebut. Sebagai tambahan, apabila peserta

\footnotetext{
${ }^{13}$ Sugiyono, 2000, Metode Penelitian Kuantitatif dan Kualitatif. Bandung : Alfabeta, p. 5

14 Denzin, Norman K., Lincoln, Yvonna, 1994, Handbook of Qualitative Research, Sage Publication, Inc., California, USA, p. 983

${ }_{15}$ Donald L. Kirkpatrick dan James D. Kirkpatrick, 2008, Evaluating Training Programs: The Four Levels, Third Edition, Berrett-Koehler Publisher Inc., San Fransisco, USA
} 
tidak bereaksi secara positif, mereka mungkin tidak akan termotivasi untuk belajar. Reaksi positif barangkali tidak menjamin belajar, tetapi kebanyakan reaksi negatif secara pasti mengurangi kemungkinan untuk mau belajar.

2. Level 2-Belajar. Belajar dapat didefinisikan sebagai, sejauh mana peserta mengubah sikap (attitude), improvisasi pengetahuan (knowledge), dan atau meningkatkan keterampilan (skill) sebagai hasil dari mengikuti program pelatihan. Ketiga hal ini adalah sesuatu yang program pelatihan dapat mencapainya. Suatu program pelatihan dikatakan berhasil apabila salah satu atau lebih dari 3 (tiga) hal diatas terjadi, baik sikap yang berubah, pengetahuan bertambah, dan keterampilan meningkat.

3. Level 3-Perilaku. Perilaku dimaksudkan disini adalah sejauh mana perubahan di dalam perilaku telah terjadi disebabkan peserta mengikuti program pelatihan. Beberapa pelatih ingin memangkas level 1 dan level 2 dalam rangka mengukur perubahan perilaku. Ini merupakan suatu kesalahan serius karena seringkali ketika perubahan perilaku tidak diketemukan dari hasil sebuah pelatihan, sudah disimpulkan bahwa program pelatihan dianggap tidak efektif dan seharusnya tidak dilanjutkan. Tentu kesimpulan ini tidak akurat. Reaksi mungkin sudah baik dan sasaran pembelajaran telah tercapai, tetapi mungkin kondisi level 3 dan 4 belum hadir.

4. Level 4-Hasil. Hasil didefinisikan sebagai hasil final yang terjadi karena peserta mengikuti program pelatihan. Hasil akhir bisa meliputi produksi yang meningkat, kualitas yang maju, biaya yang berkurang, keuntungan yang lebih tinggi dan sebagainya.

\section{Hasil Penelitian Dan Pembahasan}

\section{A. Evaluasi Level 1 (Reaksi)}

Pada tingkat ini keberhasilan suatu pelatihan dapat dievaluasi dari reaksi atau respon peserta pelatihan. Seluruh peserta sepakat menyatakan bahwa pelatihan Count Me In membantu kebutuhan dan permasalahan organisasi atau pekerjaan (Gambar 1). Variasi jawaban terletak pada tingkat kemanfaatan yang dirasakan, yakni sebagian besar peserta $(71 \%)$ menjawab sangat sesuai dengan kebutuhan dan permasalahan yang dihadapi dan $29 \%$ menyatakan sesuai dengan kebutuhan dan permasalahan yang dihadapi. Seluruh peserta juga sepakat bahwa pelatihan sesuai dengan ekspektasi atau harapan, dengan komposisi sebanyak 57\% peserta menjawab sangat setuju, adapun $43 \%$ menjawab setuju. Adapun pada item pertanyaan terkait bagian/ faktor / aspek/ hal apa saja yang membuat pelatihan Count Me In memenuhi harapan peserta pelatihan, maka jawaban yang diberikan bervariasi yakni pada aspek materi Social Marketing dan Strategi Perekrutan Volunteer. 


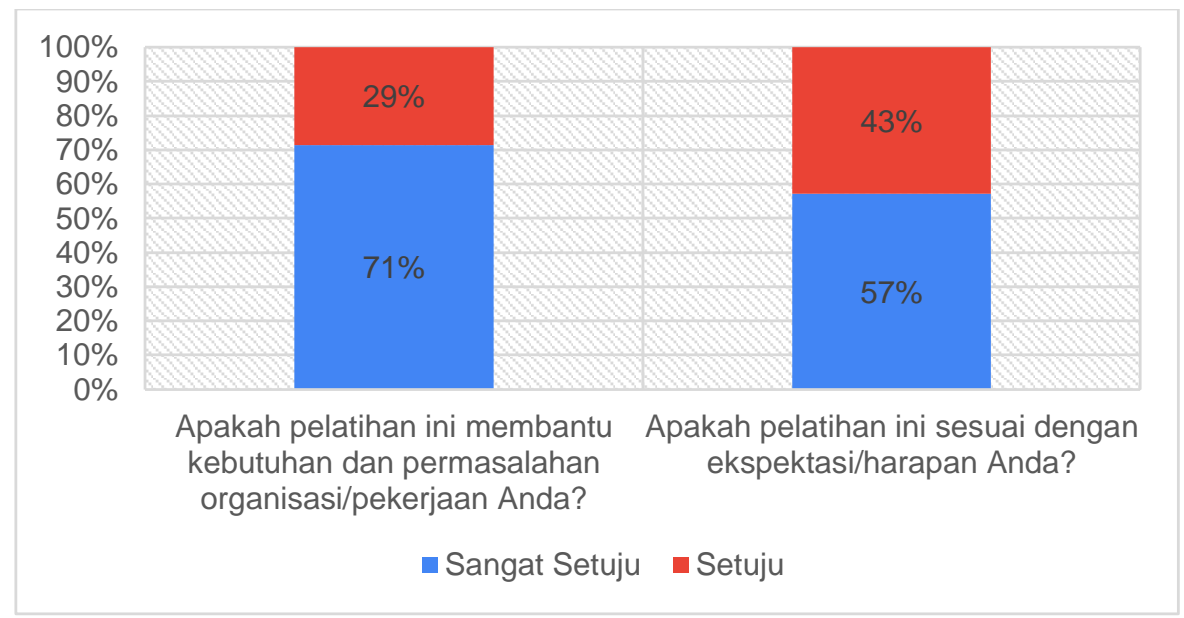

Gambar 1.

Evaluasi Level 1 Terkait Kesesuaian Training dengan Kebutuhan

Selanjutnya evaluasi terkait reaksi peserta terhadap pelatih, dalam hal ini bertujuan untuk mengetahui kepuasan peserta pelatihan terhadap performa pelatih (trainer) yang dikaji dari beberapa aspek, yaitu kinerja pelatih, cara pelatih menyampaikan materi, sikap pelatih dalam memfasilitasi setiap aktivitas peserta, dan nilai untuk pelatih. Sebagaimana tampak pada Gambar 2, seluruh peserta merasa puas terhadap kinerja (performance) pelatih dimana 43\% peserta menjawab performa trainer sangat maksimal dan 57\% peserta menjawab maksimal.

Seluruh peserta juga menyatakan dapat memahami materi pelatihan dengan baik yang ditunjukkan dengan jawaban 36\% peserta menjawab sangat mudah dipahami dan 64\% menjawab mudah dipahami. Selanjutnya seluruh peserta merasa bahwa pelatih secara komunikatif telah memfasilitasi setiap aktivitas peserta selama pelatihan berlangsung dengan perincian 57\% menyatakan sangat komunikatif dan 43\% menyatakan cukup komunikatif. Kemampuan komunikasi merupakan salah satu prasyarat keefektifan suatu kegiatan pelatihan. Kemampuan ini penting untuk mendeliver pesan-pesan atau konten materi pelatihan kepada peserta. Trainer yang baik mampu membuat peserta training memiliki skillatau keahlian sesuai materi training yang disampaikan.

Dalam Training Count Me In ini diterapkan pembelajaran andragogi. Perlunya penerapan prinsip andragogi dalam pendekatan pembelajaran orang dewasa dikarenakan upaya membelajarkan orang dewasa berbeda dengan upaya membelajarkan anak. Membelajarkan anak (pedagogi) lebih banyak merupakan upaya mentransmisikan sejumlah pengalaman dan keterampilan dalam rangka mempersiapkan anak untuk menghadapi kehidupan di masa datang. Apa yang ditransmisikan didasarkan pada pertimbangan peserta sendiri, apakah hal tersebut akan bermanfaat bagi peserta di masa datang. Sebaliknya, pembelajaran orang dewasa (andragogi) lebih menekankan pada membimbing dan membantu orang dewasa untuk 
menemukan pengetahuan, keterampilan, dan sikap dalam rangka memecahkan masalah-masalah kehidupan yang dihadapinya. Ketepatan pendekatan yang digunakan dalam penyelenggaraan suatu kegiatan pembelajaran tentu akan mempengaruhi hasil belajar.

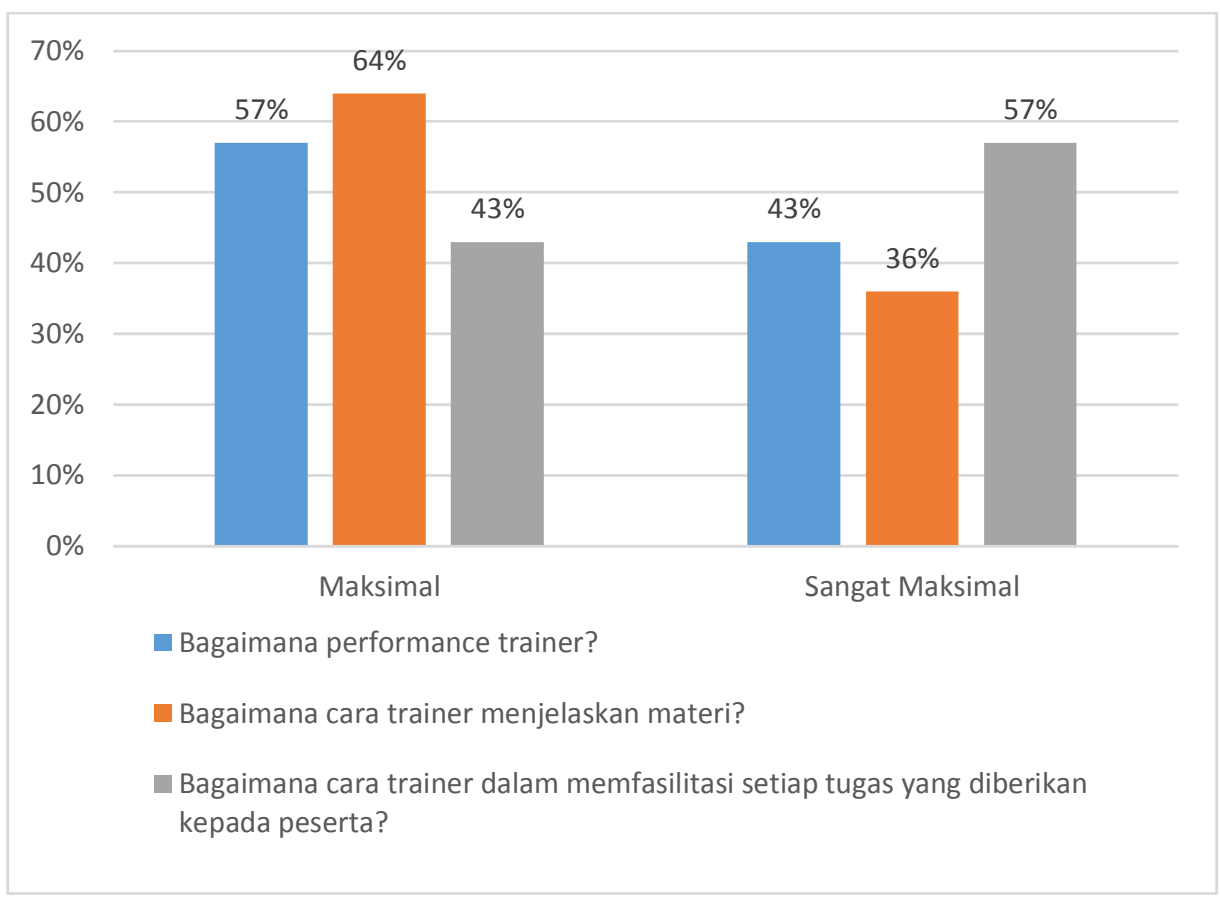

Gambar 2.

Evaluasi Level 1 Terkait Performa Trainer

Keterlibatan diri (ego peserta) adalah kunci keberhasilan dalam pembelajaran orang dewasa. Proses pelaksanaan Training Count Me In juga dilaksanakan secara dinamis dan variatif. Games dan energizer secara terus menerus berkesinambungan diberikan pada saat penyampaian materi pelatihan oleh para Trainer, sehingga peserta memperoleh insight dan pengalaman baru. Kegiatan pembelajaran dirancang secara sistematis, tahap demi tahap secara ketat, sebagaimana tujuan-tujuan pembelajaran yang telah dinyatakan secara eksplisit dan dapat diukur, kondisi belajar yang diatur dan ditentukan, serta pengalaman-pengalaman belajar yang dipilih untuk peserta. Agar belajar bermakna diperlukan inisiatif dan keterlibatan penuh dari peserta. 


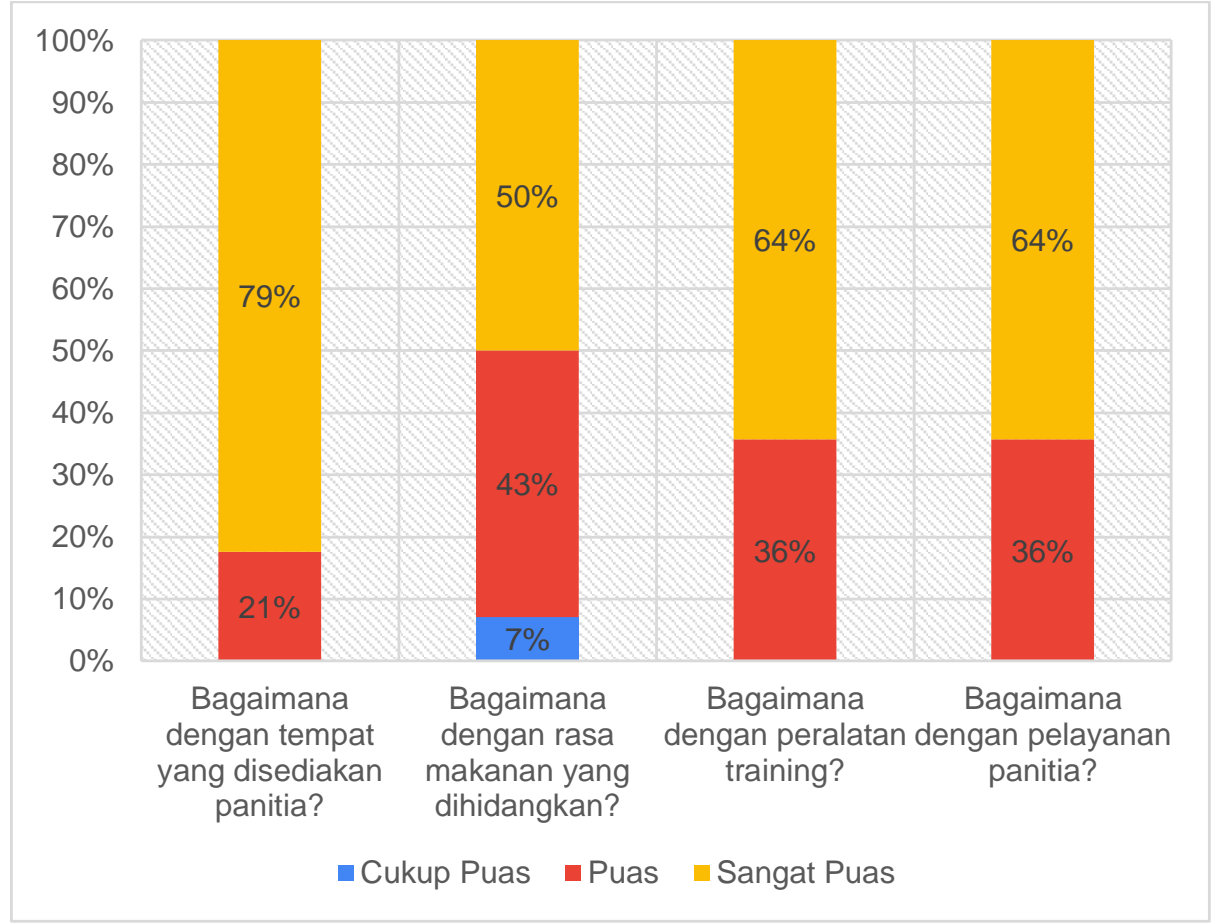

Gambar 3.

Evaluasi Level 1 Terkait Pelayanan Panitia

Terkait pelayanan panitia, secara umum peserta merasa puas, dimana 64\% menjawab sangat puas dan 36\% menjawab puas. Pelayanan panitia dalam hal ini dapat menumbuhkan semangat, minat dan motivasi peserta dalam mengikuti pelatihan. Apabila peserta bersemangat dalam mengikuti pelatihan maka hal ini akan menjadi modal yang baik dan berpengaruh positif terhadap efektivitas pelatihan. Selanjutnya seluruh peserta menyatakan bahwa fasilitas tempat pelatihan sesuai dengan harapan dimana $79 \%$ menjawab sangat puas dan $21 \%$ menjawab puas. Selain itu secara umum peserta juga merasa puas dengan konsumsi yang disediakan oleh penyelenggara dimana $50 \%$ menjawab sangat puas, $43 \%$ menjawab puas, dan $7 \%$ menjawab cukup puas. Adapun terkait dengan peralatan pelatihan yang disediakan oleh penyelenggara, 64\% peserta menjawab sangat puas dan 36\% menjawab puas.

Guna mengoptimalkan hasil pelatihan dapat mengacu pada setidaknya lima komponen yaitu (1) Staf professional yang berpengalaman, (2) Praktisi yang kompeten di bidangnya, (3) Metode partisipatisi yakni pelibatan peserta untuk aktif dalam berbagai kegiatan pembelajaran di kelas seperti diskusi, sharing pengalaman, games atau role play yang didisain sejalan dengan tujuan pelatihan, (4) Materi atau Modul Pelatihan, dan (5) Fasilitas Pelatihan, meliputi suasana kelas yang nyaman, ketersediaan peralatan pelatihan yang mendukung, fasilitas konsumsi yang mendukung, jaringan internet yang dapat diakses gratis dan fasilitas pendukung lainnya. Fasilitas tempat pelatihan berpengaruh terhadap minat dan motivasi peserta dalam mengikuti kegiatan pelatihan. 


\section{B. Evaluasi Level 2-Belajar}

Kirkpatrick (1998) mengemukakan "learning can be defined as the extend to which participans change attitudes, improving knowledge, and/ or increase skill as a result of attending the program". Dengan demikian, efektifitas pelatihan, dalam level ini, diukur dari dampaknya terhadap peserta. Apakah setelah pelatihan berakhir ada perubahan dari aspek pengetahuan, ketrampilan atau perilaku kerja ke arah yang lebih baik, sesuai tujuan diselenggarakannya pelatihan.

Pengukuran hasil belajar dapat dilakukan dengan berbagai cara, salah satunya dengan melakukan pre test dan post test, yaitu peserta diberikan tes terlebih dahulu sebelum pelatihan dijalankan dan sesudah pelatihan dijalankan. Dalam Pelatihan Count Me In ini Pelatih telah dirancang pre test dan post test setiap hari selama 4 (empat) hari pelaksanaan pelatihan. Berikut disajikan contoh salah satu perbandingan hasil pre test dibanding post test :

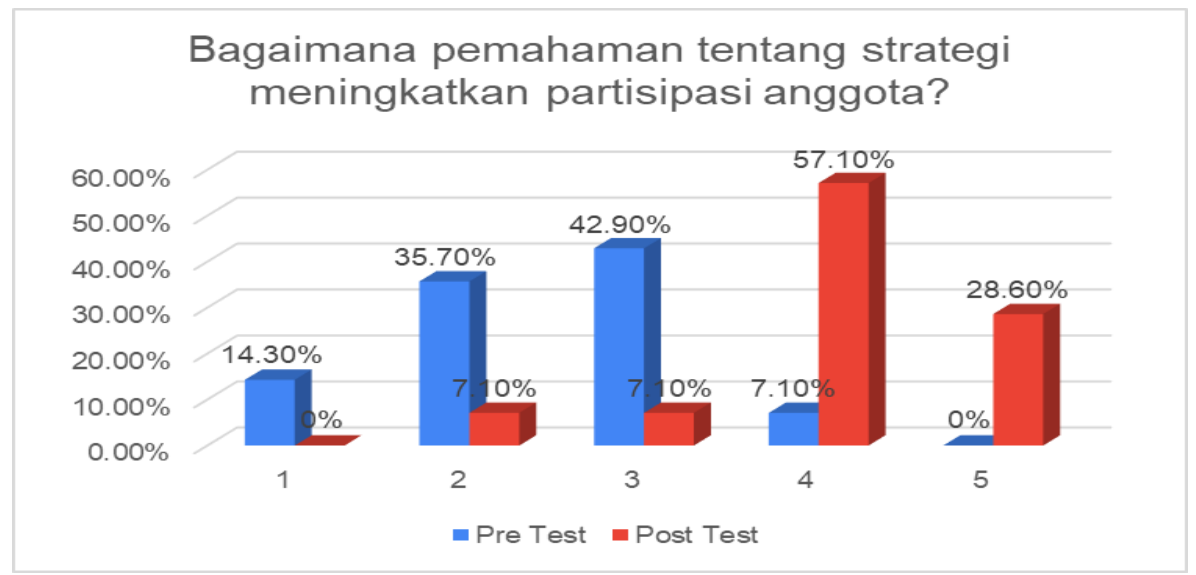

Gambar 4.

Perbandingan Pengetahuan Peserta Pelatihan Pre Test dan Post Test (1)

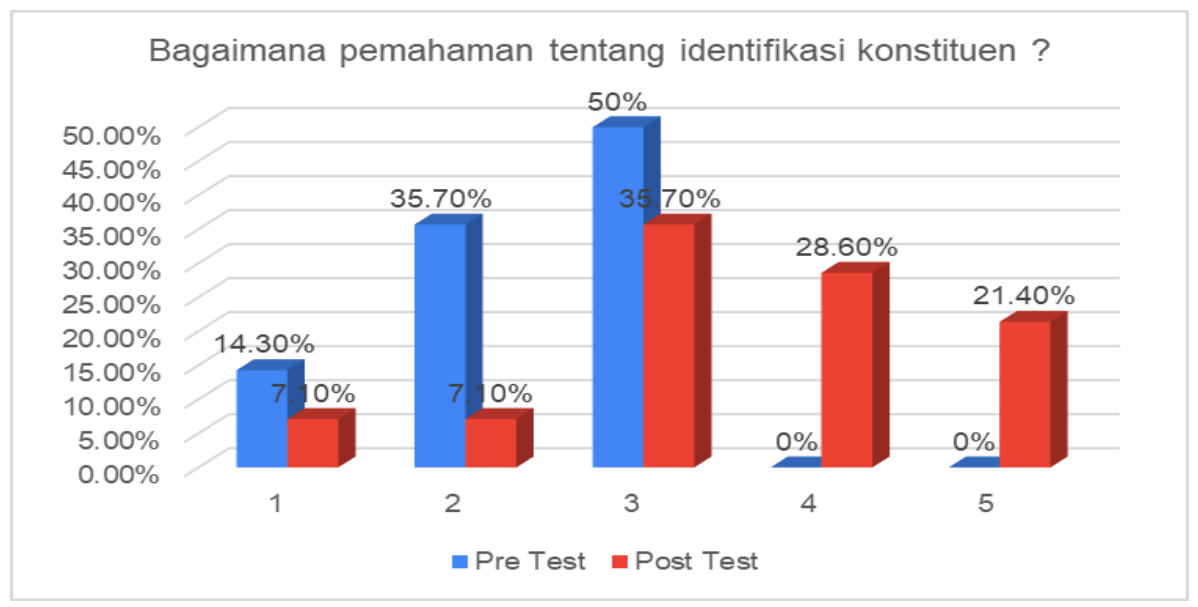

Gambar 5.

Perbandingan Pengetahuan Peserta Pelatihan Pre Test dan Post Test (2) 
Pada Gambar 4, item pertanyaan pemahaman peserta terhadap strategi meningkatkan partisipasi anggota, menunjukkan ada peningkatan aspek pengetahuan. Pada saat Pre Test, dari rentang skor nilai 1 hingga 5, ternyata menunjukkan hasil sebanyak 14,3\% peserta yang memperoleh skor 1, sebanyak 35,7\% peserta yang memperoleh skor 2, sebanyak $42,9 \%$ peserta memperoleh skor 3 , sebanyak $7,1 \%$ peserta memperoleh skor 4 dan sebanyak $0 \%$ peserta memperoleh skor 5 . Adapun setelah pelaksanan Training Count Me In dan dilakukan Post Test dengan rentang skor nilai 1 hingga 5, menunjukkan hasil adanya peningkatan skor pengetahuan peserta, yakni ada sebanyak $0 \%$ peserta yang memperoleh skor 1 (skor turun sebesar 14,3\%), sebanyak 7,1\% peserta yang memperoleh skor 2 (skor turun sebesar 28,6\%), sebanyak $7,1 \%$ peserta memperoleh skor 3 (skor turun sebesar 35,8\%), selanjutnya sebanyak $57,1 \%$ peserta memperoleh skor 4 (terjadi kenaikan skor pengetahuan sebesar $50 \%$ ) dan sebanyak $28,6 \%$ peserta memperoleh skor 5 (terjadi kenaikan skor pengetahuan sebesar 28.6\%).

Pada Gambar 5, item pertanyaan pemahaman peserta tentang identifikasi konstituen, menunjukkan ada peningkatan aspek pengetahuan. Pada saat Pre Test, dari rentang skor nilai 1 hingga 5, ternyata menunjukkan hasil sebanyak 14,3\% peserta yang memperoleh skor 1 , sebanyak $35,7 \%$ peserta yang memperoleh skor 2 , sebanyak $50 \%$ peserta memperoleh skor 3 , sebanyak $0 \%$ peserta memperoleh skor 4 dan sebanyak $0 \%$ peserta memperoleh skor 5. Adapun setelah pelaksanan Training Count Me In dan dilakukan Post Test dengan rentang skor nilai 1 hingga 5, menunjukkan hasil adanya peningkatan skor pengetahuan peserta, yakni ada sebanyak $7,1 \%$ peserta yang memperoleh skor 1 (skor turun sebesar 7,2\%), sebanyak 7,1\% peserta yang memperoleh skor 2 (skor turun sebesar 26,6\%), sebanyak 35,7\% peserta memperoleh skor 3 (skor turun sebesar 14,3\%), selanjutnya sebanyak 28,6\% peserta memperoleh skor 4 (terjadi kenaikan skor pengetahuan sebesar 28.6\%) dan sebanyak 21,4\% peserta memperoleh skor 5 (terjadi kenaikan skor pengetahuan sebesar 21,4\%).

Demikian pula terjadi kenaikan skor pengetahuan pada keseluruhan item pertanyaan yang lain.

\section{Evaluasi Level 3-Perilaku}

Evaluasi training level 3 ini lebih memfokuskan pada evaluasi pelatihan Count Me In dari aspek perubahan perilaku. Kalau pada level 2, evaluasi pelatihan hanya menekankan perubahan sikap (internal), pada level 3, evaluasi akan menilai apakah setelah mengikuti pelatihan peserta mengalami perubahan perilaku yang berdampak pada kinerja. Oleh karena itu, pada evaluai pelatihan pada level ini disebut sebagai evaluasi terhadap outcomes pelatihan.

Beberapa item pertanyaan terkait perubahan perilaku dalam Training Count Me In sebagai berikut :

1. Apakah ada perubahan perilaku dalam pengelolaan kesukarelawanan? 
2. Apakah ada perubahan perubahan perilaku lebih aktif dalam mensosialisasikan pengelolaan kesukarelawanan?

3. Apakah ada perubahan perilaku dalam memotivasi rekan kerja untuk melakukan perubahan yang lebih baik dalam pengelolaan kesukarelawanan?

4. Apakah ada perubahan perilaku untuk lebih konsisten dalam pengelolaan kesukarelawanan?

Dari wawancara terbuka yang dilakukan terhadap beberapa CSO dapat diketahui bahwa perubahan perilaku dimaksud sebagai berikut :

1. Dimulainya ide untuk membuat program orientasi dan program pelatihan relawan. Dalam hal ini konsep program relawan disesuaikan dengan warna lembaga

2. Menjadi tahu akan pentingnya memahami kejelasan arah gerak lembaga mempergunakan VMOSA (Vission, Mission, Objectives, Strategies and Action Plan) dan selanjutnya mencoba mengimplementasikan dalam pengelolaan kesukarelawanan

3. Memacu semangat dalam mempertahankan para relawan yang sudah ada dan berupaya menambah relawan-relawan yang baru.

4. Melakukan perbaikan dalam sistem pengelolaan kesukarelawanan.

\section{Evaluasi Level 4-Hasil}

Evaluasi training pada level 4 menekankan pada hasil akhir (result) setelah mengikuti pelatihan. Hasil akhir dalam hal ini dapat berupa indikator-indikator kinerja yang nyata seperti kenaikan jumlah volunteer, peningkatan kemampuan melatih volunteer, peningkatan kemampuan pengembangan program pelatihan untuk volunteer, dan lainlain. Beberapa item pertanyaan terkait perubahan perilaku dalam Tarining Count Me In sebagai berikut :

1. Apakah ada peningkatan kreativitas dalam pengelolaan sukarelawan?

2. Apakah ada peningkatan disiplin peserta dalam pengelolaan sukarelawan?

3. Apakah ada peningkatan tanggungjawab dalam pengelolaan sukarelawan?

4. Apakah ada peningkatan keterampilan dalam pengelolaan sukarelawan?

5. Apakah ada peningkatan kemampuan dalam mencari solusi dari setiap permasalahan yang dihadapi dalam pengelolaan sukarelawan?

6. Apakah ada peningkatan kemampuan dalam mencari solusi dari setiap permasalahan yang dihadapi dalam pengelolaan sukarelawan?

7. Apakah ada peningkatan kemampuan dalam melakukan relasi positif dengan orang lain dalam pengelolaan sukarelawan?

8. Apakah ada peningkatan kemampuan dalam melakukan relasi positif dengan orang lain dalam pengelolaan sukarelawan di luar organisasi?

9. Apakah ada peningkatan kemampuan dalam menghadapi perubahan lingkungan yang berasal dari dalam organisasi? 
10. Apakah ada peningkatan kemampuan dalam menghadapi perubahan lingkungan yang berasal dari luar organisasi?

11. Apakah ada peningkatan keterampilan dalam bekerja sehingga lebih efisien?

12. Apakah ada manfaat penerapan materi pelatihan terhadap kinerja pribadi?

13. Apakah ada manfaat penerapan materi pelatihan terhadap kinerja organisasi?

Secara umum dari hasil wawancara terbuka yang dilakukan terhadap beberapa CSO diperoleh data dan informasi bahwa untuk evaluasi level 4 sebagai berikut :

1. Realisasi program kerelawanan saat ini sedang dalam proses implementasi

2. CSO bekerja sama dalam memperluas jaringan. CSO juga bekerjasama dalam mempertahankan relawan-relawan yang sudah ada. Namun disadari bahwa upaya tersebut belum maksimal.

Untuk melihat hasil program pelatihan setelah peserta kembali ke organisasi CSO masing-masing dan ada tidaknya perubahan perilaku peserta usai mendapatkan pelatihan memang tidak mudah dilakukan evaluasinya. Evaluasi yang harus ditempuh oleh tim pelatih/tim pendampingan adalah dilakukan pengamatan langsung dan pengamatan partisipatif di tempat dimana organisasi CSO tersebut berada dan berkegiatan. Wawancara juga dilakukan dengan para alumni peserta pelatihan, atasan langsung mereka dan triangulasi diantara rekan sejawat guna mengetahui ada tidaknya perubahan pengetahuan, keterampilan, sikap dan perilaku. Hingga saat ini pendampingan (coaching) setelah Training Count Me In terhadap lembaga CSO sedang berada dalam proses pelaksanaan sehingga evaluasi Level 3 dan evaluasi Level 4 berada dalam proses observasi lebih mendalam.

\section{Catatan Akhir}

Berdasar temuan, pembahasan dan analisa yang telah dilakukan tim peneliti dapat dikemukakan beberapa kesimpulan sebagai berikut: pertama, pelaksanaan Pelatihan Count $\mathrm{Me}$ In secara umum berjalan efektif dan dapat dilanjutkan menurut evaluasi program pelatihan berbasis 4 (empat) level Kirkpatrick, terutama Evaluasi Level 1 dan Level 2. Meskipun dalam penyelenggaraannya tetap harus didahului dengan Training Need Assesment (TNA), penyesuaian, pengayaan dan modifikasi isi (content) materi program pelatihan, dan kesiapan tim pelatih dan dukungan manajemen pelatihan serta fasilitas pelatihan, Adapun Evaluasi Level 3 dan Level 4 secara umum telah menunjukkan hasil yang positif meski perlu terus dilakukan pendampingan yang berkelanjutan.

Kedua, tujuan dan target dari Pelatihan Count Me In secara umum tercapai sesuai dengan rencana dan mendapatkan reaksi yang positif dari peserta pelatihan walaupun bervariasi tingkatan responnya, berkisar sangat baik, baik dan cukup baik. Taka da satu pun reaksi negative dari peserta pelatihan.

Ketiga, Keluaran (output) dari Pelatihan Count Me In adalah pengetahuan dan keterampilan baru bagi peserta terutama tools strategi, metode dan tehnik-tehnik rekruitmen dan pembinaan relawan yang atraktif dan inovatif. 


\section{Acknowledgement}

Pendanaan penelitian ini didukung oleh NICE Foundation Indonesia bekerjasama dengan NAMA Foundation. Untuk itu Tim Peneliti mengucapkan terima kasih atas fasilitas dan dukungan yang diberikan.

\section{Daftar Rujukan}

Armstrong, David, Valeria Bello, J. Gilson, D.Spini, 2011, Civil Societ and International Governance: the Role of Non-State Actors in Global and Regional Regulary Frameworks, First Published, Routledge/GARET-series, Europe, USA

Biech, Elaine, 2017, the Art and Science of Training, the Association of Talent Development (ATD) Press, USA

Boxall, Peter, Purcell, John, Wright, Patrick, 2007, The Oxford Handbook of Human Resources Management, Oxford University Press Inc., USA

Chruden, Herbert J., Sherman, Arthur W., 1984, Managing Human Rosources, Seventh Edition, South-West Publishing Co., Ohio, USA

Creswell, John W., 2007, Qualitative Inquiry and Research Design: Choosing Among Five Approaches, Second Edition, Sage Publication, California, USA

Denhart, Janet V, Robert B. Denhart, 2007, the New Public Service: Serving Not Steering, Expanded Edition, M.E. Sharpe Inc, New York, USA

Denzin, Norman K., Lincoln, Yvonna, 1994, Handbook of Qualitative Research, Sage Publication, Inc., California, USA

Edwards, Michael, 2011, The Oxford Handbook Of Civil Society, Oxford University Press, Oxford

Kirkpatrick, Donald L., Kirkpatrick, James D., 2008, Evaluating Training Programs: The Four Levels, Third Edition, Berrett-Koehler Publisher Inc., San Fransisco, USA

Rochester, Angela E.Paine, Zimmeck, 2010, Volunteering and Society in the 21st Century, Palgrave MacMillan Pubsliher, USA

Salamon, Lester M., Helmut K. Anheier, et.al., 1999, Global Civil Society: Dimensions of the Nonprofit Sector, The John Hopkins Center for Civil Society Studies, Baltimore, USA

Suprajogo, Tjahjo, 2011, Manajemen Pelayanan Publik Dalam Paradigma Baru Pemerintahan: Konsep, Desain dan Implementasi, Institut Pemerintahan Dalam Negeri, Jakarta

Tyson, Shaun, 2006, Essentials of Human Resource Management, Fifth Edition, Published by Elsevier Ltd, USA

Wilson, John dan Mare Musick, 1997, Who Cares? Toward an Integrated Theory of Volunteer Work, American Sociological Review, Vol 62 (October) 